\title{
Predicting the age and weight at puberty of Ongole Grade cattle using nonlinear mathematical model in Kebumen Farmer Association
}

\author{
D. Maharani ${ }^{1}{ }^{*}$, A. H. K. Amrullah ${ }^{1}$, D. T. Widayati ${ }^{1}$, Sumadi $^{1}$, A. Fathoni ${ }^{1}$ and M. Khusnudin ${ }^{2}$ \\ ${ }^{1}$ Faculty of Animal Science, Universitas Gadjah Mada, \\ Jl. Fauna No. 3, Bulaksumur, Yogyakarta 55281 - Indonesia \\ ${ }^{2}$ Kebumen PO Cattle Breeder Association (ASPOKEB), \\ Tanggulangin Village, Klirong Subdistrict, Kebumen, Jawa Tengah - Indonesia \\ *Corresponding E-mail:d.maharani@ugm.ac.id
}

Received April 28, 2017; Accepted July 28, 2017

\begin{abstract}
ABSTRAK
Penelitian ini bertujuan untuk mengevaluasi penggunaan model matematika non-linear dalam memprediksi umur dan bobot saat pubertas sapi Peranakan Ongole (PO). Data yang digunakan berupa catatan bobot badan (768) ekor sapi PO, mulai dari umur baru lahir $(<1$ bulan) sampai dewasa $(60$ bulan), dan telah dikumpulkan oleh Asosiasi Peternak Sapi PO Kebumen (ASPOKEB) Kebumen dari tahun 2013 sampai 2015. Ternak sapi dipelihara oleh kelompok ternak yang berada di enam kecamatan yaitu Kecamatan Mirit, Lembu Purwo, Ambal, Puring, Petanahan, dan Puring yang berada di Kabupaten Kebumen, Jawa Tengah. Analisis data menggunakan model matematika Brody, Bertalanfy, Logistic, dan Gompertz. Hasil analisis menunjukkan bahwa tingkat kesesuaian dari keempat model tersebut dapat digolongkan dalam kategori tinggi $\left(R^{2}>0.70\right)$. Bobot dewasa (A) sapi PO paling tepat diprediksi oleh model Logistic (349 kg) dan Gompertz (358 kg). Model Logistic paling tepat dalam memprediksi bobot pubertas $(174 \mathrm{~kg})$ sapi PO, akan tetapi seluruh sapi yang diamati masih pada fase follikuler.
\end{abstract}

Kata Kunci: Bobot dewasa, titik belok, Logistic, Gompertz, smear vagina

\begin{abstract}
This research is aimed to evaluate the nonlinear mathematical model in predicting the age and weight of Kebumen Ongole Grade (PO) cattle at puberty. The data used in this research was weight recordings of (768) PO cattle, ranging from calf $(<1$ month) to adult (60 months), collected by Kebumen PO cattle Breeder Association (ASPOKEB) from 2013 to 2015. These cattle were reared by a group of farmers located in six sub-districts: Mirit, Lembu Purwo, Ambal, Puring, Petanahan, and Klirong in Kebumen district, Jawa Tengah Province. Brody, Bertalanfy, Logistic and Gompertz mathematical models were used to analyze the data. The analysis showed that the $R^{2}$ of the four models classify high in the category $\left(R^{2}>0.70\right)$. Mature weight (A) of PO cattle predicted by Logistic $(349 \mathrm{~kg})$ and Gompertz $(358 \mathrm{~kg})$ were most appropriate. Out of the four models, the Logistic model was the most accurate in predicting the weight at puberty $(174 \mathrm{~kg})$ of PO cattle, but all observed cattle are still in the follicular phase.
\end{abstract}

Keywords :Inflection point, Mature weight, Logistic, Gompertz, Vaginal smear 


\section{INTRODUCTION}

Ongole Grade (PO) cattle is the result of crossbreeding between Javanese cattle with Ongole cattle from India (starting from 1904). It was then developed from generation to next generations by the people in Central Java and East Java Provinces. Through decree no. $2841 / \mathrm{Kpts} / \mathrm{LB} .430 / 8 / 2012$, PO cattle is recognized as a local breed by the Indonesian government. PO cattle has grown into an established breed with recognized morphological characteristics. PO cattle has the advantages of tropical cattle such as adaptability in tropical climate, resistance to heat and parasites, and good tolerance to cattle feed containing a high crude fiber (Astuti, 2004). The cattle are raised with a traditional system in which every farmer has two to three cattle with varying raising environment, enabling it to have a varied biologic potential. Since its development, little effort has been made to improve its biological and genetic potential.

Body weight is believed to be the most important trait in evaluating the cattle production capacity (Lee et al., 2014). Body weight is affected by the growth rate of each individual animal. Budimulyati et al. (2012) states growth was divided into two phases, positive and negative. Growth rate accelerates during the positive phase, while on the negative phase the growth rate decreases. The transition point from the two different phases will pinpoint the inflection point of a cattle growth graph. Determining the transition point requires an appropriate model, for conventional models only use a regressing linear calculation that are not able to explain the phenomena (Brody, 1945).

The age of puberty and growth rate can be described in a growth curve. In turn, growth curve can be described using mathematical models. The appropriate mathematical model which is easy to interpret biologically and analytically is the nonlinear model (Maharani et al., 2001). The mathematical models that are commonly used are Brody, Von Bertalanfy, Gompertz, and Logistic (Budimulyati et al., 2012).

The application of nonlinear mathematical model had been done on some research such as Saanen goat growth (Rocha et al., 2015), fat tailed goat growth (Hamouda and Atti, 2011), and male Gujarat cattle growth (Loaiza-Echeverrri et al., 2013). In Indonesia, the application of nonlinear mathematical models was growth and age puberty in Brahman Cross cattle (Maharani et al., 2001),
Holstein Frisian cattle growth (Budimulyati et al., 2012) and rabbit growth (Setiaji et al., 2013). The application of nonlinear mathematical model to predict the puberty age and growth rate of $\mathrm{PO}$ cattle has never been done. The results of this study supposed to be useful for Kebumen PO Cattle Breeder Association (ASPOKEB) to select their cattle based on desire trait which can be predicted using the appropriate model. Moreover, selection animals based on the recording data will be more value economically. Therefore, the objecive of the study was to evaluate the application of nonlinear mathematical model in predicting age and weight during puberty of female Ongole Grade cattle which are owned and bred by ASPOKEB.

\section{MATERIALS AND METHODS}

\section{Data Collection}

The data used in this study were body weight of 768 female PO cattle, from the age of birth $(<1$ month) to mature (66 months). These cattle are from six sub-districts Mirit, Lembu Purwo, Ambal, Klirong, Petanahan, and Puring. The cattle weight data are collected by PO Cattle Breeder Association (ASPOKEB) from the year 2013 to 2015.

The data used consist of body weight and the age of the cattle. Cattle age data was obtained from recordings in each breeder group, which were then calculated to determine the age of each cattle. Body weight data is obtained from recording cattle weighing from the year 2013 to 2015. The weighing of body weight was done using a cattle scale with a $1000 \mathrm{~kg}$ capacity and an error margin of $1 \mathrm{~kg}$. The type of data used are cross sectional data, in which data collection were performed by measuring the weight of individual cattle in a certain age group, followed by the measurement of other individual samples within the same population (Fitzhugh, 1976).

\section{Mathematical Model}

The mathematical models used consisted of Brody, Von Bertalanfy, Logistic, and Gompertz, as explained by Forni et al. (2014) and Budimulyati et al. (2012). The equations of mathematical models are presented in Table 1.

\section{Determining Onset of Puberty}

Determining the age and weight at puberty was performed by discovering the inflection point in the growth curve. Inflection point is a 
Table 1. The Equation of Four Mathematical Models

\begin{tabular}{llccc}
\hline \multicolumn{1}{c}{ Model } & \multicolumn{1}{c}{$\mathrm{Yt}$} & $\mathrm{M}$ & Weight of inflection & Inflection time \\
\hline Brody & $\mathrm{A}\left(1-\mathrm{Be}^{-\mathrm{kt}}\right)$ & 1 & $\ldots \ldots \ldots$. & $\ldots \ldots \ldots$ \\
Bertalanfy & $\mathrm{A}\left(1-\mathrm{Be}^{-\mathrm{kt}}\right)^{3}$ & 3 & $\mathrm{~A}(8 / 27)$ & $\ln 3 \mathrm{~B} / \mathrm{k}$ \\
Logistic & $\mathrm{A}\left(1+\mathrm{Be}^{-\mathrm{kt}}\right)^{-1}$ & -1 & $\mathrm{~A}(0,5)$ & $\ln \mathrm{B} / \mathrm{k}$ \\
Gompertz & $\mathrm{Ae}\left(-\mathrm{Be} \mathrm{e}^{-\mathrm{kt}}\right)$ & $\mathrm{M} \rightarrow \infty$ & $\mathrm{A}\left(\mathrm{e}^{-1}\right)$ & $\ln \mathrm{B} / \mathrm{k}$ \\
\hline
\end{tabular}

$\mathrm{Yt}=$ Body weight on $\mathrm{t}$ of age, $\mathrm{A}=$ Mature body weight (Asimtot), $\mathrm{B}=$ The proportion of mature weight which will reached after birth weight formed by Yo and early $t$ (the value of integral constants), $e=$ Basic of logarithm (2,718282), $\mathrm{k}=$ the animal growth rate reach on mature body weight, $\mathrm{M}=$ Parameter which obtained the point of inflection in a curve

maximum point of growth in body weight. At that point there is a shift change showing the acceleration of the growth becomes slow down in growth. At that point the animals reach their puberty (Brody, 1945). Inflection point was performed by using equations of mathematical model as presented in Table 1.

Vaginal smear test was used to determine the best mathematical model in predicting age puberty. Vaginal smear test was conducted by rubbing a cotton bud that has been moistened with aquadest on the walls of the vagina, which then smeared onto glass slides. Next, the slides were soaked with $70 \%$ alcohol for 5 to 7 minutes, then it was soaked with $5 \%$ Giemsa stain for 45 minutes. Glass slides were then rinsed with aquadest and dried. Colored glass slides were observed with an electron microscope with a magnification of 20 times to observe the development of cells in the vaginal wall. Vaginal smear was done every 3 days, for 21 days.

\section{Data Analysis}

To determine whether there is a difference in value between $\mathrm{A}, \mathrm{B}$, and $\mathrm{k}$ from each tested mathematical model, the models were tested using One-way ANOVA. Duncan multiple range test (DMRT) was used to determine wheter the A, B, and $\mathrm{k}$ coefficients for each models were significantly different (Topal et al., 2004).

\section{Goodness-of-fit}

Coefficient of determination $\left(R^{2}\right)$ and mean square error (MSE) were used to determine the best fit of model (Topal et al., 2004). The $R^{2}$ and MSE have been indicated in non linear regression results calculted using SPSS ver 17. The smaller of MSE value, and the bigger of $R^{2}$ value $(>70 \%)$, are more fit the mathematical model used in predicting the studied variable.

\section{RESULTS AND DISCUSSIONS}

\section{Body Weight}

Variations in body weight in various age groups are presented in Table 2 and it can be generated by different environmental and genetic factors and their interaction. Genetic influences at each animal will respond differently to the same environmental conditiions. Environmental influences can be caused by differences in feed management applied by each farmer. Indonesia has two seasons: rainy season and dry season. There is a significant difference in cattle feed availability between the two seasons (Sanz-Saez et al., 2012). The research done by Zarate Martinez et al. (2013) on Zebu cattle showed a difference between birth weight and weaning weight on each season and birth year. ZarateMartinez et al. (2013) added that management in keeping livestock that affects quantity, quality, and the continuity of feed supply, especially before and after weaning will result in delaying the growth of the livestock.

Swali et al. (2008) noted that growth rate varies between individuals in ages above 6 months old. The animal undergoes an accelerated growth rate at the age of 3 to 6 months old, it decreases afterwards. Figure 1 shows a graph of the curve that connects between body weight and age. The curve discribes the growth pattern of PO cattle in Kebumen District.

The result indicated that the overall growth curve depicted by each mathematical model follows the nonlinear growth curve patterns with precise depictions $\left(R^{2}>0.7\right)$. The growth rate 
Table 2. The Average PO Cattle Body Weight and Standard Deviation in Several Age Levels (months)

\begin{tabular}{cccccc}
\hline $\begin{array}{c}\text { Age } \\
(\text { month })\end{array}$ & $\begin{array}{c}\text { BW } \pm \text { SD } \\
(\mathrm{kg})\end{array}$ & $\begin{array}{c}\text { Age } \\
(\text { month })\end{array}$ & $\begin{array}{c}\text { BW } \pm \text { SD } \\
(\mathrm{kg})\end{array}$ & $\begin{array}{c}\text { Age } \\
(\text { month })\end{array}$ & $\begin{array}{c}\text { BW } \pm \text { SD } \\
(\mathrm{kg})\end{array}$ \\
\hline 1 & $45.0 \pm 6.00$ & 11 & $173 \pm 37.5$ & 21 & $259 \pm 38.7$ \\
2 & $72.2 \pm 13.7$ & 12 & $203 \pm 52.7$ & 22 & $277 \pm 69.9$ \\
3 & $76.2 \pm 16.9$ & 13 & $203 \pm 53.4$ & 24 & $290 \pm 59.8$ \\
4 & $116 \pm 25.3$ & 14 & $181 \pm 47.7$ & 25 & 272 \\
5 & $123 \pm 26.5$ & 15 & $184 \pm 33.4$ & 26 & 280 \\
6 & $131 \pm 27.9$ & 16 & $224 \pm 56.1$ & 30 & $318 \pm 32.4$ \\
7 & $137 \pm 33.5$ & 17 & $220 \pm 56.5$ & 36 & $330 \pm 34.8$ \\
8 & $154 \pm 47.2$ & 18 & $214 \pm 51.2$ & 42 & $358 \pm$ \\
9 & $158 \pm 37.2$ & 19 & $216 \pm 37.8$ & 48 & $357 \pm 21.2$ \\
10 & $176 \pm 47.6$ & 20 & $254 \pm 49.3$ & 54 & $358 \pm$ \\
& & & & 60 & $345 \pm 24.6$ \\
\hline
\end{tabular}

$\mathrm{BW}=$ Body weight, $\mathrm{SD}=$ standard deviation

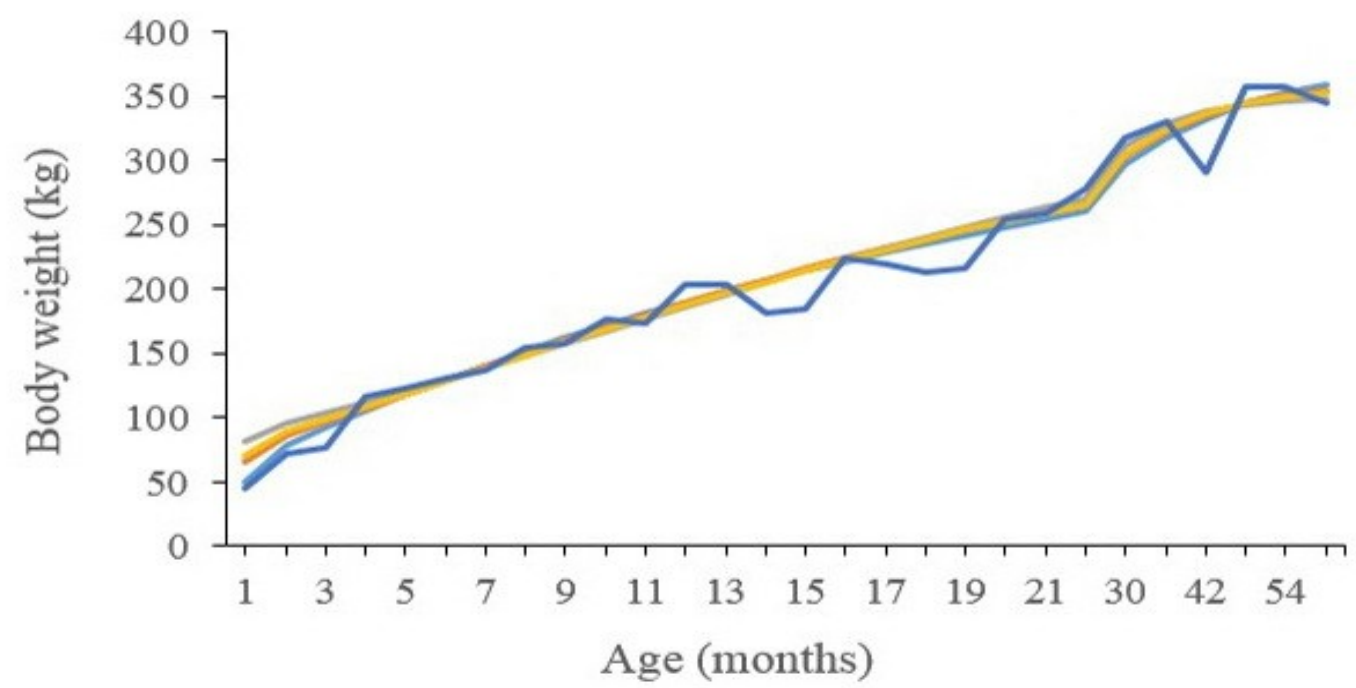

Figure 1. Graph of Ongole Grade Cattle Growth

-Brody - Bertalanfy - Logistic

- Gompertz —observed data

predicted by each mathematical model occurs at the time of birth until the point of inflection. The growth rate begins to decrease from the point inflection until the cattle reaches mature weight (348 to $363 \mathrm{~kg}$ ) at the age ranging from 42 to 48 months, and then the growth rate begins to decrease until it becomes constant. Bertalanfy,
Logistic, and Gompertz models all overestimated their prediction of weight from the age of 1 to 4 months and 12 to 14 months. All three mathematical model also underestimated their prediction of weight from the age 13 to 20 months. Bahashwan et al. (2015) said that Bertalanfy, Gompertz, and Logistics models were 
overestimated in describing growth curve of Dhofari cattle at age of 24 until 60 months old.

Weaning age also affects the growth. Results from Sudrajad's (2013) research stated that cattle breeders in Kebumen usually wean calves at the age of 5 to 7 months, where Guggeri et al. (2014) noted cattle that are weaned early will have a more substantial weight compared to those who are weaned traditionally. Guggeri et al. (2014) suggested that calves that are weaned early and fed with high energy feed have an ADG exceeding $1 \mathrm{~kg} /$ day.

\section{Growth Parameter}

The result of parameter analysis based on Brody, Bertalanfy, Logistic, and Gompertz mathematical models are shown on Table 3. The value of parameter A (mature weight) in Bertalanfy model have significantly $(\mathrm{P}<0.05)$ difference compared to Brody, Gompertz, and Logistic models. While the value of parameter A in Brody, Gompertz, and Logistic models do not show significantly $(\mathrm{P}<0.05)$ difference. The result of Topal's et al. (2004) research showed a value difference in parameter A in Brody's model compared to Bertalanfy, Gompertz, and Logistic. Budimulyati et al. (2012) stated that the highest value of parameter A was achieved by Bertalanfy's model, followed by Gompertz's and Richard's.

The value of parameter B in Logistic model is different compared to Bertalanfy, Brody, and Gompertz models. The value of parameter B in Gompertz model is also different compared to Bertalanfy's and Brody's, while there are no difference in the value of parameter B between Bertalanfy and Brody. The highest parameter $\mathrm{k}$ value was achieved by Logistic model, in which there are no differences in $\mathrm{k}$ parameter value in each models. The $\mathrm{k}$ value indicates that growth

Table 3. Prediction of Age and Weight Onset Puberty

\begin{tabular}{lcc}
\hline \multicolumn{1}{c}{ Model } & $\begin{array}{c}\text { Weight of } \\
\text { Inflection }(\mathrm{kg})\end{array}$ & $\begin{array}{c}\text { Inflection } \\
\text { Iime }(\text { month })\end{array}$ \\
\hline Brody & $\ldots \ldots \ldots$. & $\ldots \ldots \ldots$ \\
Bertalanfy & 108 & 7.26 \\
Logistic & 174 & 10.90 \\
Gompertz & 132 & 6.32 \\
\hline
\end{tabular}

rate of a cattle is relative to its mature weight. Cattle with a high $\mathrm{k}$ value will reach mature weight faster than those who have smaller $\mathrm{k}$ value with the same starting weight (Malhado et al., 2009).

This study's research indicated that PO cattle reached $349 \mathrm{~kg}$ body weight at the age of 4 to 5 years. Maharani et al. (2001) stated that cattle at the age 4 to 5 years will reaches mature weight. The most appropriate model for predicting the weight of mature PO cattle are Logistic and Gompertz models. Maharani et al. (2001) reported that Logistic models is the most accurate in predicting parameter A value in Brahman Cross cattle. However, Budimulyati et al. (2012) obtained a different result, in which Gompertz model described the most accurately to predict $A$.

Brody's model has the highest determination coefficient $\left(R^{2}=0.74\right)$ and the lowest mean square error $(\mathrm{MSE}=1491.39)$. The $R^{2}$ high value indicates that variations which arises in weight (Y) can be explained by the Brody's model equation followed by Bertalanfy, Logistic, and Gompertz. Although Brody's model has the highest suitability, but this model does not describe the age and weight at puberty, growth rate, and mature growth rate. The $R^{2}$ value obtained from the four models in this study is smaller than those found in Budimulyati's et al. (2012), Topal's et al. (2004), Maharani et al. (2001), Hamouda's and Atti's (2011) and Zarate Martinez's et al. (2013) research, with each $R^{2}$ numbering (0.98), (0.98), (0.92), (0.99) and (0.97). The difference in result is thought to be because of the high variety of data in each age group, although the sample size is relatively large. Body weight data from different breeds reared in different environments would influence the goodness of fit of the mathematical model in explaining the variations in body weight in cattle (Hafiz et al., 2015).

\section{Prediction of Age and Weight onset Puberty}

Research results in Table 4 shows that the Gompertz model predicts the age of puberty younger than Bertalanfy and Logistic models. The age of puberty of Ongole crossbreed cattle based on Gompertz model is achieved at the age of 6.32 months of age with a weight of $132 \mathrm{~kg}$ at puberty. Bertalanfy's model predict the age of puberty at the age of 7.26 months with a weight of $108 \mathrm{~kg}$. Logistic's model predict the age of puberty at the age of 10.90 months with a weight of $174 \mathrm{~kg}$. Zarate Martinez et al. (2013) stated that Zebu 
cattle reaches puberty when its weight reaches $55 \%$ mature weight. If calculated based on the average mature weight of PO cattle at the age of 4 to 5 years $(394 \mathrm{~kg})$, the cattle reaches $192 \mathrm{~kg}$ during puberty. The most accurate model in describing weight during puberty is the Logistic model. The same result has also been found by Maharani et al. (2001) and Budimulyanti et al. (2013), which stated that the Logistic models is the most accurate in predicting the weight of Brahman Cross cattle (143 kg) and Holstein Friesian $(146 \mathrm{~kg})$, as opposed to the other models.

\section{Vaginal Smear Test}

Vaginal smear test was conducted to check the development of vaginal cellular wall in female PO cattle suspected of undergoing puberty. The determination of cattle suspected of undergoing puberty will be based on the puberty age predictions calculated using nonlinear mathematical models. Puberty age estimate using Logistic, Bertalanfy, and Gompertz models were 10.9 months $(n=7), 7.26$ months $(n=4)$, dan 6.32 months $(n=4)$.

The vaginal cells of PO cattle suspected to undergoing puberty, based on the predictions using Logistic, Bertalanfy, and Gompertz models can be observed in Figure 2. Overall, the observed PO cattle are still in their follicular phase (development of follicles). This indicates that all the observed cattle have not entered their puberty phase. Each model underestimated their puberty age prediction. This due to the fact that the cattle have not reached their puberty weight. Rudolf (2010) stated that the first estrus will occur when the cattle reaches the minimum weight, rather than reaching a certain age. Puberty in cattle are influenced by genetics (Nogueira, 2004), feed and weaning age (Guggeri et al., 2014), maintenance management and climate (Chebel et al., 2007). These factors will indefinitely affect to body weight and cattle growth levels (Abeygunawardena and Dematewewa 2004). Limited feeding will lead to the late of puberty, while the giving of supplements into the cattle feed will increase growth and accelerate the start of puberty (Guggeri et al., 2014).

\section{CONCLUSION}

All the evaluated nonlinear mathematical models in this study have a high level $(>0.70)$ of $R^{2}$. Brody's model was the most appropriate model in predicting growth with high

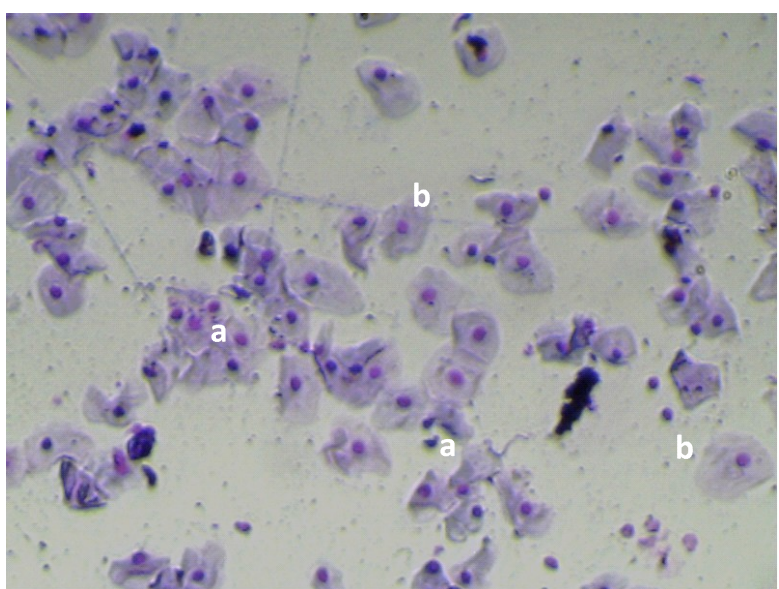

Figure 2. Smear from vaginal epithel PO cattle during follicular phase.

a. Parabasal cells (nucleated clear, regular round shape and small cytoplasm,

b. Intermediate cells (nucleated, irregular shape, and larger cytoplasm.

determination coefficient $\left(R^{2}=0.74\right)$ and the low mean square error $(\mathrm{MSE}=1491.39)$. Mature wight of PO cattle predicted by Logistic $(349 \mathrm{~kg})$ and Gompertz $(358 \mathrm{~kg})$ models were the most appropriate based on body weight data. Logistic model was most appropriate model for predicting weight of PO cattle at puberty $(174 \mathrm{~kg})$ based on body weight data, but all observed cattle are still in the follicular phase.

\section{ACKNOWLEDGEMENT}

The authors gratefully acknowledge the PO Cattle Breeder Association (ASPOKEB) in Kebumen district, Indonesia for their willingness on providing the data on their animals recording. This research was supported by Graduate Research Grant from the Faculty of Animal Science, Universitas Gadjah Mada with contract No. 1997/J01.1.25/PASCA/2015

\section{REFERENCES}

Abeygunawardena, H. and C.M.B. Dematawewa. 2004. Pre-pubertal and postpartum anestrus in tropical zebu cattle. J. Anim. Reprod. Sci. 82:373-387.

Astuti, M. 2004. Potensi dan keragaman sumber daya genetik sapi peranakan ongole. Wartazoa. 14:98-106.

Bahashwan, S., A.S. Alrawas, S. Alfadli and E.S. 
Johnson. 2015. Dhofari cattle growth curve prediction by different non-linear model functions. Livest. Res. Rural Dev. 27:12.

Brody, S. 1945. Bioenergetics and Growth. Reinhold Publishing Corp., New York, NY.

Budimulyati, L.S., R.R. Noor, A. Saefuddin and C. Talib. 2012. Comparison on accuracy of logistic, gompertz, and von bertalanffy models in predicting growth of new born calf until first mating of Friesian Holstein heifers. J. Indonesian Trop. Anim. Agric. 37:151-160.

Chebel, R.C., F.A. Braga and J.C. Dalton. 2007. Factors affecting reproductive performance of Holstein heifers. J. Anim. Reprod. Sci. 101:208-224.

Fitzhugh, H.A. 1976. Analysis of growth curve and strategies for altering their shape. J. Anim. Sci. 42:10361-1051.

Forni, S., M. Piles, A. Blasco, L. Varona, S.H.N. Oliveira, R.B. Lobo and L.G. Albuquerque. 2014. Comparison of different nonlinear functions to describe nelore cattle growth. J. Anim. Sci. 87:496-506.

Guggeri, D., A. Meikle, M. Carriquiry, F. Montossi and I. De Barbieri. 2014. Effect of different management systems on growth, endocrine parameters and puberty in hereford female calves grazing campos grassland. J. Livest. Sci. 167:4555-462.

Hafiz, M.A.W., M.R. Hifzan, I.A.J. Bahtiar and O.M. Ariff. 2015. Describing growth pattern of brakmas cows using nonlinear regression models. Mal. J. Anim. Sci. 18:37-45.

Hamouda, M.B. and N. Atti. 2011. Comparison of growth curves of lamb fat tail measurement and their relationship with body weight in babarine sheep. Small Rum. Res. 95:120127.

Lee, J.H., S.-H. Oh, Y.M. Lee, Y.S. Kim, H.J. Son, D.J. Jeong, N.C. Whitley and J.J. Kim. 2014. Study on growth curves of Longisimus dorsi muscle area, backfat thickness and body conformation for Hanwoo (Korean Native) cows. Asian-Aust. J. Anim. Sci. 27:1250-1253.

Loaiza-Echeverri, A.M., J.A.G. Bergmann, F.L.B. Toral, J.P. Osorio, A.S. Carmo, L.F. Mendonca, V.S. Moustacas and M. Henry. 2013. Use of nonlinear models for describing scrotal circumference growth in guzerat bulls raised under grazing conditions. Theriogenology. 79:751-759.
Maharani, D., M. Astuti and Sumadi. 2001. Evaluasi penerapan model matematik nonlinear dalam memprediksi laju pertumbuhan sapi Brahman cross di PT BULI. Agrosains. 14:339-346.

Malhado, C.H.M., P.L.S. Carneiro, P.R.A.M. Affonso, A.A.O. Souza and J.L.R. Sarmento. 2009. Growth curves in Dorper sheep crossed with the local Brazilian breeds, Morada Nova, Rabo Largo, and Santa Ines. Small Rum. Res. 84:16-21.

Rocha, N.S., R.A.M. Vieira, M.L.C. Abreu, R.P. Araujo, L.S. Gloria, W.P. Tamy, C.H.P.C. Nova and A.M. Fernandez. 2015. Traditional and biphasic nonlinear models to describe growth of goat kids of specialized dairy breeds. Small Rum. Res. 123:35-46.

Rudolf, F.O. 2010. Puberty in Beef Heifers: A Review. Jurnal Ilmu Peternakan. 20-27.

Sanz-Saez, A., G. Erice, J. Aguirreolea, J.J. Irigoyen and M. Sanchez-Diaz. 2012. Alfalfa yield under elevated $\mathrm{CO}_{2}$ and temperature depends on the Sinorhizobiumstrain and growth season. J. Exp. Bot. 77:267-273.

Sudrajad,P., Subiharta and N. Qomariyah. 2013. Potensi daun Gliricidia sp sebagai pakan alternatif untuk pedet sapi peranakan ongole (PO) lepas sapih di Kabupaten Kebumen. Prosiding seminar nasional. Makassar 19-21 June. BPTP Sulawesi Selatan. 1:765-772.

Setiaji, A., Sutopo and E. Kurnianto. 2013. Growth analysis in rabbit using gompertz non-linear model. J. Indonesian Trop. Anim. Agric. 38:92-97

Swali, A., Z. Cheng, N. Bourne and D.C. Wathes. 2008. Metabolic traits affecting growth rates of pre-pubertal calves and their relationship with subsequent survival. Domestic. Anim. Endocrinol. 35:300-313.

Topal, M., M. Ozdemir, V. Aksakal, N. Yildiz and U. Dogru. 2004. Determination of the best nonlinear function in order to estimate growth in Morkaraman and Awassi lambs. Small Rum. Res. 55:229-232.

Zarate-Martinez, J.P., V.D. Hernandez-Hernandez, J.C. Vinay-Vadillo, J.A. Villagomez-Cortes and A. Rios-Utrera. 2013. Effect of environmental factors from birth to the onset of reproductive function and management in Indo-Brazilian Heifers. Int. J. Anim. Vet. Adv. 5:61-66. 